Article

\title{
Production of Hydrogen-Rich Gas by Oxidative Steam Reforming of Dimethoxymethane over $\mathrm{CuO}-\mathrm{CeO}_{2} / \gamma-\mathrm{Al}_{2} \mathrm{O}_{3}$ Catalyst
}

\author{
Sukhe Badmaev ${ }^{1,2, *}$ and Vladimir Sobyanin ${ }^{1}$ \\ 1 Boreskov Institute of Catalysis, 630090 Novosibirsk, Russia; sobyanin@catalysis.ru \\ 2 Department of Natural Sciences, Novosibirsk State University, Pirogova St. 2, 630090 Novosibirsk, Russia \\ * Correspondence: sukhe@catalysis.ru
}

Received: 25 June 2020; Accepted: 14 July 2020; Published: 17 July 2020

check for updates

\begin{abstract}
The catalytic properties of $\mathrm{CuO}-\mathrm{CeO}_{2}$ supported on alumina for the oxidative steam reforming (OSR) of dimethoxymethane (DMM) to hydrogen-rich gas in a tubular fixed bed reactor were studied. The $\mathrm{CuO}-\mathrm{CeO}_{2} / \gamma-\mathrm{Al}_{2} \mathrm{O}_{3}$ catalyst provided complete DMM conversion and hydrogen productivity $>10 \mathrm{~L} \mathrm{~h}^{-1} \mathrm{gcat}^{-1}$ at $280{ }^{\circ} \mathrm{C}$, GHSV (gas hourly space velocity) $=15,000 \mathrm{~h}^{-1}$ and DMM: $\mathrm{O}_{2}: \mathrm{H}_{2} \mathrm{O}: \mathrm{N}_{2}=10: 2.5: 40: 47.5$ vol.\%. Comparative studies showed that DMM OSR exceeded DMM steam reforming (SR) and DMM partial oxidation (PO) in terms of hydrogen productivity. Thus, the outcomes of lab-scale catalytic experiments show high promise of DMM oxidative steam reforming to produce hydrogen-rich gas for fuel cell feeding.
\end{abstract}

Keywords: dimethoxymethane; hydrogen production; $\mathrm{CuO}-\mathrm{CeO}_{2} / \gamma-\mathrm{Al}_{2} \mathrm{O}_{3}$; oxidative steam reforming; partial oxidation; copper catalyst; fuel cell

\section{Introduction}

Growing worldwide concerns about the increase in greenhouse gas emission and local environmental pollution have stimulated active research and development in fuel cell technology in the past decades [1]. There is no doubt that fuel cells will play an important role in the global restructuring of energy supply, because they have several advantages over conventional power units such as high efficiency, noiseless operation, simple and modular design and environmental friendliness [2]. Generally, fuel cells are fed by hydrogen or hydrogen-containing gas produced by the catalytic conversion of various hydrocarbons and oxygenates [3-5].

Recently, dimethoxymethane (DMM) has been declared as a promising environmentally safe raw material for hydrogen production for fuel cell feeding [6-16]. At present, DMM is commonly synthesized from methanol $[17,18]$. It is worth noting that DMM synthesis using renewable feedstocks-namely, $\mathrm{CO}_{2}$ produced from biomass and hydrogen generated by water electrolysis-is currently under development [19]. Since DMM is a relatively inert (non-corrosive and non-toxic) liquid compound, it can be easily handled, stored and transported.

Analysis of the current literature shows that DMM can be converted into hydrogen-rich gas by steam reforming (SR) (1) [6-14], decomposition (2) [15] and partial oxidation (PO) (3) [16] at relatively low temperatures. The reactions of DMM conversion are shown as follows:

$$
\begin{gathered}
\mathrm{CH}_{3} \mathrm{OCH}_{2} \mathrm{OCH}_{3}+4 \mathrm{H}_{2} \mathrm{O}=8 \mathrm{H}_{2}+3 \mathrm{CO}_{2} \\
\mathrm{CH}_{3} \mathrm{OCH}_{2} \mathrm{OCH}_{3}=\mathrm{H}_{2}+\mathrm{CO}+\mathrm{CH}_{3} \mathrm{OCH}_{3} \\
\mathrm{CH}_{3} \mathrm{OCH}_{2} \mathrm{OCH}_{3}+0.5 \mathrm{O}_{2}=4 \mathrm{H}_{2}+3 \mathrm{CO}
\end{gathered}
$$


Among these catalytic methods, steam reforming is the most efficient in terms of maximum hydrogen yield and negligible $\mathrm{CO}$ content. In accordance with the kinetic scheme of the DMM SR reaction, effective $\mathrm{CuO}-\mathrm{CeO}_{2}$ and $\mathrm{CuO}-\mathrm{ZnO}$ catalysts supported on $\gamma-\mathrm{Al}_{2} \mathrm{O}_{3}$ have been proposed in our group [8-11]. Since DMM SR is a highly endothermic reaction $\left(\Delta \mathrm{H}^{0}{ }_{298}=+140 \mathrm{~kJ} / \mathrm{mol}\right)$, the use of conventional granulated catalysts causes the formation of cold spot temperature gradients in the catalyst bed, resulting in reduced activity. Therefore, a solution suggested in our previous work [12], depositing the active catalytic components for DMM SR on metallic FeCrAl wire mesh support, was quite successful. However, an obvious drawback of using $\mathrm{FeCrAl}$ mesh support is a significant increase in the reactor volume.

It is well known that the temperature distribution in the catalytic reactor can be optimized by a combination of steam reforming (1) and partial oxidation (3) reactions [20-22]. The oxidative steam reforming (OSR) of hydrocarbons and oxygenates is being studied not only to minimize the cold/hot spot effect in the catalytic reactor, but in some cases the reaction shows enhanced effectivity over steam reforming or partial oxidation [20,21]. In particular, Velu et al. [20,21] found that methanol OSR was more efficient in many aspects than methanol SR and methanol PO for hydrogen production. Moreover, the presence of oxygen in the reaction mixture helps to control coking by the efficient removal of carbonaceous species produced during the reaction [22].

Inspired by the above-mentioned works, and by the fact that no studies have been conducted on DMM OSR to date (literature survey revealed no references devoted to the reaction), herein we report the first example of the titled reaction to produce hydrogen-rich gas for fuel cell feeding. In our experiments, we used the $\mathrm{CuO}-\mathrm{CeO}_{2} / \gamma-\mathrm{Al}_{2} \mathrm{O}_{3}$ catalyst which is known for its high activity and selectivity in DMM SR [8,9]. A comparative investigation of partial oxidation as well as steam reforming of DMM was performed to elucidate the prospects of DMM OSR in producing hydrogen-rich gas with low $\mathrm{CO}$ content for fuel cell feeding.

\section{Materials and Methods}

The catalyst 10 wt.\% $\mathrm{CuO}-5$ wt. $\% \mathrm{CeO}_{2}$ supported on $\gamma-\mathrm{Al}_{2} \mathrm{O}_{3}$ (further denoted as $\left.\mathrm{CuO}-\mathrm{CeO}_{2} / \gamma-\mathrm{Al}_{2} \mathrm{O}_{3}\right)$, which demonstrated good performance in DMM SR reaction [8,9], was used in the OSR and PO catalytic experiments. The catalyst was prepared by impregnating $\gamma-\mathrm{Al}_{2} \mathrm{O}_{3}\left(200 \mathrm{~m}^{2} / \mathrm{g}\right.$, $0.25-0.5 \mathrm{~mm}$ particles) with aqueous solutions of copper (II) and cerium (III) nitrates as described in detail in [8,9]. According to [9], the catalyst contained on its surface the Lewis acid sites of $\gamma-\mathrm{Al}_{2} \mathrm{O}_{3}$ (active sites for DMM hydrolysis to methanol and formaldehyde) and copper species as $\sim 10 \mathrm{~nm}$ particles and agglomerates containing both copper and cerium (responsible for methanol and formaldehyde SR).

DMM OSR as well as DMM PO were studied using a fixed-bed flow reactor (i.d. $6 \mathrm{~mm}$ ) in the temperature range $150-330^{\circ} \mathrm{C}$ under ambient pressure $(1 \mathrm{~atm})$. The reactor has two inlets for a separate supply of $\mathrm{O}_{2}$ and DMM to prevent homogeneous DMM oxidation in the gas phase, as reported in our recent work [16]. The DMM- $\mathrm{H}_{2} \mathrm{O}-\mathrm{N}_{2}$ and $\mathrm{O}_{2}$ flows were immediately mixed before entering the catalyst bed. The catalyst temperature was measured by a chromel/alumel thermocouple positioned in the center of the catalyst bed. Prior to the SR and OSR reactions (except partial oxidation), the catalyst $(0.25-0.5 \mathrm{~mm})$ was reduced in situ at $300{ }^{\circ} \mathrm{C}$ for $1 \mathrm{~h}$ using 5 vol. $\% \mathrm{H}_{2} / \mathrm{N}_{2}$ with a total flow rate of $3000 \mathrm{~mL} / \mathrm{h}$.

Then, the catalyst was exposed to the feed composed of (vol.\%): $16.7 \mathrm{DMM}, 16.7 \mathrm{O}_{2}$ and $66.6 \mathrm{~N}_{2}$ (DMM:air $\approx 1: 5$ ) for DMM PO; $10 \mathrm{DMM}, 40 \mathrm{H}_{2} \mathrm{O}, 2.5 \mathrm{O}_{2}$ and $47.5 \mathrm{~N}_{2}$ for DMM OSR; $10 \mathrm{DMM}, 0-45 \mathrm{H}_{2} \mathrm{O}$, 0-10 $\mathrm{O}_{2}$ and $45-80 \mathrm{~N}_{2}$ for comparative investigation. Note that the reagents were significantly diluted by $\mathrm{N}_{2}$ exceeding 40 vol.\% in order to correctly measure the reaction mixture composition during catalyst testing. Total GHSV (gas hourly space velocity) was maintained at $10,000 \mathrm{~h}^{-1}$. Comparative investigations were performed at GHSV $=15,000 \mathrm{~h}^{-1}$ as special experiments.

The deionized water was injected by a plunger pump into an evaporator at $120^{\circ} \mathrm{C}$. DMM was fed to the catalytic reactor by bubbling $\mathrm{N}_{2}$ through a glass saturator filled with $99.5 \%$ purity DMM (Acros Organics) maintained at $20^{\circ} \mathrm{C}$. Additional $\mathrm{N}_{2}$ and $\mathrm{O}_{2}$ were fed to get the required reaction 
mixture. All the gases, $\mathrm{N}_{2}, \mathrm{O}_{2}$ and $\mathrm{H}_{2}$ (for catalyst reduction) were introduced to the reactor by a mass-flow controller (Bronkhorst). The inlet reaction mixture and the outlet products were analyzed online by a gas chromatograph (Chromos-1000) equipped with two TCD detectors maintained at $130{ }^{\circ} \mathrm{C}$. Argon was used as a carrier gas. DMM and $\mathrm{O}_{2}$ conversion $(\mathrm{X}), \mathrm{H}_{2}$ productivity $(\mathrm{W})$ and yields $(\mathrm{Y})$ of carbon-containing products were calculated by the following equations:

$$
\begin{gathered}
X_{i}(\%)=\frac{C_{i}^{0}-C_{i} \times \frac{C_{N_{2}}^{0}}{C_{N_{2}}}}{C_{i}^{0}} \times 100 \\
W_{H_{2}}\left(\frac{L}{h \cdot g_{\text {cat }}}\right)=\frac{F \times C_{\mathrm{H}_{2}} \times \frac{C_{N_{2}}^{0}}{C_{N_{2}}}}{100 \times m_{\text {cat }}} \\
Y_{i}(\%)=\frac{C_{i} \times \frac{C_{N_{2}}^{0}}{C_{N_{2}}}}{\left(C_{D M M}^{0}\right) \times N_{i}} \times 100
\end{gathered}
$$

where $\mathrm{C}^{0}, \mathrm{C}$ are the inlet and outlet concentrations, $\mathrm{F}$ is the total reagents flow rate $(\mathrm{L} / \mathrm{h}), \mathrm{m}_{\text {cat }}$ is the catalyst weight $(\mathrm{g})$, and $\mathrm{N}_{\mathrm{i}}$ is the number of carbon molecules in the compound.

\section{Results}

\subsection{DMM Partial Oxidation}

Recently, we proposed an efficient $\mathrm{Pt} / \mathrm{CeO}_{2}-\mathrm{ZrO}_{2}$ catalyst for DMM PO to syngas, showing high promise for Solid Oxide Fuel Cells (SOFC) applications [16]. The low cost of copper compared to noble metals, as well as the good performance of copper-containing catalysts in the partial oxidation of methanol [23] and dimethyl ether [24], encouraged our studies of DMM PO over the $\mathrm{CuO}-\mathrm{CeO}_{2} / \gamma-\mathrm{Al}_{2} \mathrm{O}_{3}$ catalyst.

Figure 1 shows the effect of reaction temperature on DMM and $\mathrm{O}_{2}$ conversions, as well as the reaction product concentrations during DMM PO over the $\mathrm{CuO}-\mathrm{CeO}_{2} / \gamma-\mathrm{Al}_{2} \mathrm{O}_{3}$ catalyst using the reaction mixture $\mathrm{CH}_{3} \mathrm{OCH}_{2} \mathrm{OCH}_{3}: \mathrm{O}_{2}: \mathrm{N}_{2}=16.7: 16.7: 66.6$ vol. $\%$ at $\mathrm{GHSV}=10,000 \mathrm{~h}^{-1}$. Under these conditions, the $\mathrm{O}_{2}$ conversion was $100 \%$ in the whole test temperature range. DMM conversion was $\sim 70 \%$ at $150{ }^{\circ} \mathrm{C}$, which increased with increasing temperature and reached $\sim 100 \%$ at $200{ }^{\circ} \mathrm{C}$.

As can be seen in Figure 1, two nominal temperature ranges at $150-200{ }^{\circ} \mathrm{C}$ and $250-330{ }^{\circ} \mathrm{C}$ with characteristic product distribution were observed. In the first range, $\mathrm{CO}_{2}$ and $\mathrm{CH}_{3} \mathrm{OH}$ were predominantly formed (> 13 vol.\% concentration). In addition, $\mathrm{H}_{2}, \mathrm{CO}, \mathrm{CH}_{3} \mathrm{OCH}_{3}$ and $\mathrm{H}_{2} \mathrm{O}$ were observed in an amount not exceeding 6 vol.\%. Then, as the temperature increased (second range), the product distribution changed drastically; $\mathrm{CH}_{3} \mathrm{OH}$ and $\mathrm{H}_{2} \mathrm{O}$ concentrations decreased to 0 with simultaneous increase in $\mathrm{H}_{2}$ and $\mathrm{CO}$ concentrations, respectively, up to 26 and 7-9 vol.\%. Note that $\mathrm{CO}_{2}$ concentration remained almost unchanged at $150-330^{\circ} \mathrm{C}$. Dimethyl ether (DME) concentration was about 3 vol. $\%$ at $150{ }^{\circ} \mathrm{C}$, passed through a maximum $(8 \mathrm{vol} . \%)$ at $250{ }^{\circ} \mathrm{C}$ and lowered to 5 vol. $\%$ with further temperature increase up to $330{ }^{\circ} \mathrm{C}$.

Analysis of the product distributions, taking into account the recent papers on DMM hydrolysis [9], DMM decomposition [15], methanol [23] and DME [24,25] partial oxidation, helps us to clarify the kinetic scheme of the DMM PO reaction over the $\mathrm{CuO}-\mathrm{CeO}_{2} / \gamma-\mathrm{Al}_{2} \mathrm{O}_{3}$ catalyst. In our opinion, initially, DMM total oxidation (7) most likely proceeds in the frontal layer of the catalyst [23]. The produced water hydrolyzes DMM to methanol and formaldehyde (8) on the acid sites of $\gamma-\mathrm{Al}_{2} \mathrm{O}_{3}$ [9]:

$$
\begin{gathered}
\mathrm{CH}_{3} \mathrm{OCH}_{2} \mathrm{OCH}_{3}+4 \mathrm{O}_{2}=3 \mathrm{CO}_{2}+4 \mathrm{H}_{2} \mathrm{O} \\
\mathrm{CH}_{3} \mathrm{OCH}_{2} \mathrm{OCH}_{3}+\mathrm{H}_{2} \mathrm{O}=2 \mathrm{CH}_{3} \mathrm{OH}+\mathrm{CH}_{2} \mathrm{O}
\end{gathered}
$$




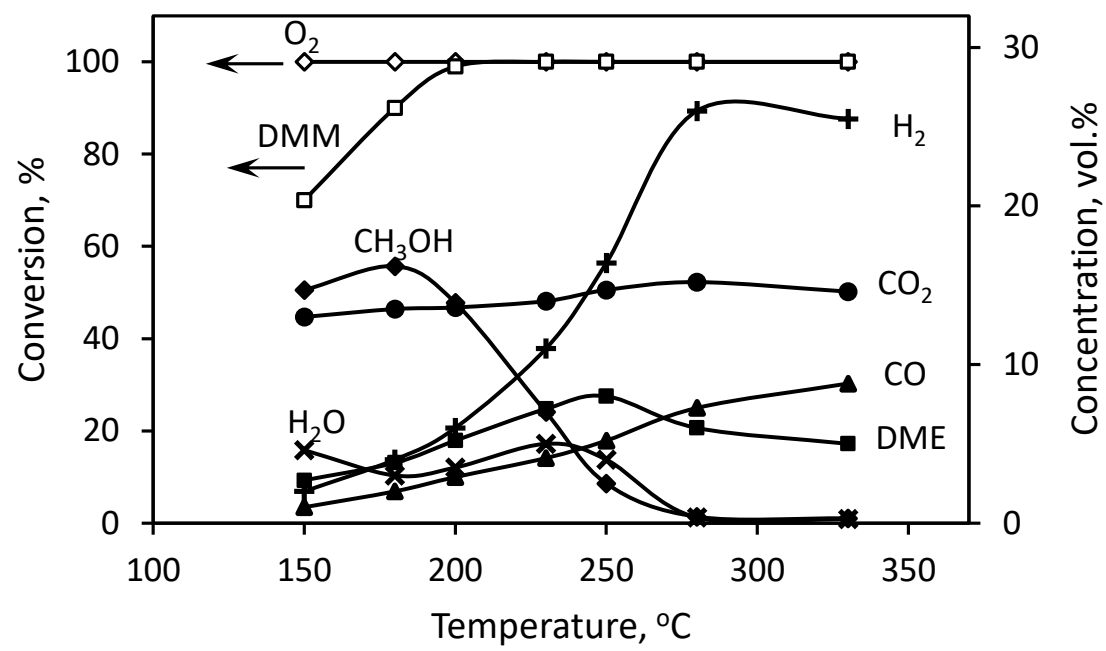

Figure 1. Effect of reaction temperature on dimethoxymethane (DMM) conversion and outlet concentrations in DMM partial oxidation (PO) over $\mathrm{CuO}-\mathrm{CeO}_{2} / \gamma-\mathrm{Al}_{2} \mathrm{O}_{3}$ catalyst. Reaction conditions: $\mathrm{P}=1 \mathrm{~atm}$; GHSV (gas hourly space velocity) $=10,000 \mathrm{~h}^{-1}$; Inlet composition: $\mathrm{CH}_{3} \mathrm{OCH}_{2} \mathrm{OCH}_{3}: \mathrm{O}_{2}: \mathrm{N}_{2}$ $=16.7: 16.7: 66.6$ vol. $\%$.

However, formaldehyde was not detected in the reaction products, probably due to its higher reactivity $(9,10)$ compared to methanol on the copper-containing catalyst [26].

$$
\begin{gathered}
\mathrm{CH}_{2} \mathrm{O}+\mathrm{H}_{2} \mathrm{O}=2 \mathrm{H}_{2}+\mathrm{CO}_{2} \\
\mathrm{CH}_{2} \mathrm{O}=\mathrm{H}_{2}+\mathrm{CO}
\end{gathered}
$$

Thus, consideration of reactions (7)-(10) adequately explains the product distribution in the low-temperature region. At higher temperatures $\left(250-330{ }^{\circ} \mathrm{C}\right)$ methanol can be converted to hydrogen-rich gas on the copper-based catalysts by steam reforming (11) or decomposition (12) reactions $[4,23,26]$ :

$$
\begin{gathered}
\mathrm{CH}_{3} \mathrm{OH}+\mathrm{H}_{2} \mathrm{O}=3 \mathrm{H}_{2}+\mathrm{CO}_{2} \\
\mathrm{CH}_{3} \mathrm{OH}=2 \mathrm{H}_{2}+\mathrm{CO}
\end{gathered}
$$

As for DME, its formation can be realized by a DMM decomposition reaction (2). A decrease in its concentration at $>250{ }^{\circ} \mathrm{C}$ is probably associated with an increase in the reaction mixture volume during the DMM PO reaction (3).

Figure 2 shows the effect of time-on-stream on the $\mathrm{DMM}$ and $\mathrm{O}_{2}$ conversions, the outlet product concentrations in DMM PO over the $\mathrm{CuO}-\mathrm{CeO}_{2} / \gamma-\mathrm{Al}_{2} \mathrm{O}_{3}$ catalyst. The stability experiment was carried out at $280^{\circ} \mathrm{C}$, with the inlet composition $\mathrm{CH}_{3} \mathrm{OCH}_{2} \mathrm{OCH}_{3}: \mathrm{O}_{2}: \mathrm{N}_{2}=16.7: 16.7: 66.6$ (vol.\%) and GHSV $=10,000 \mathrm{~h}^{-1}$. Under these conditions, complete DMM and $\mathrm{O}_{2}$ conversions were provided. As seen in Figure 2, during the first hour on-stream, $\mathrm{H}_{2}, \mathrm{CO}_{2}, \mathrm{CO}$ and DME were the main reaction products, while only traces of $\mathrm{CH}_{4}, \mathrm{CH}_{3} \mathrm{OH}$ and $\mathrm{H}_{2} \mathrm{O}$ were detected not exceeding 0.3 vol.\%. Unlike DMM SR $[8,9]$, the $\mathrm{CuO}-\mathrm{CeO}_{2} / \gamma-\mathrm{Al}_{2} \mathrm{O}_{3}$ demonstrated continuous deactivation during the first $6 \mathrm{~h}$ on DMM PO stream in terms of $\mathrm{H}_{2}$ and $\mathrm{CO}$ concentrations (Figure 2). Then the outlet product concentrations remained constant and did not change with time.

Thus, the feasibility of DMM PO on a copper-containing catalyst was demonstrated for the first time. Although the $\mathrm{CuO}-\mathrm{CeO}_{2} / \gamma-\mathrm{Al}_{2} \mathrm{O}_{3}$ catalyst was not sufficiently stable during the DMM PO, the first example of the reaction is quite promising. Obviously, it seems appropriate to perform further studies aimed at developing a more active and stable copper-based catalyst for DMM PO as well as detailed reaction mechanism investigations. 


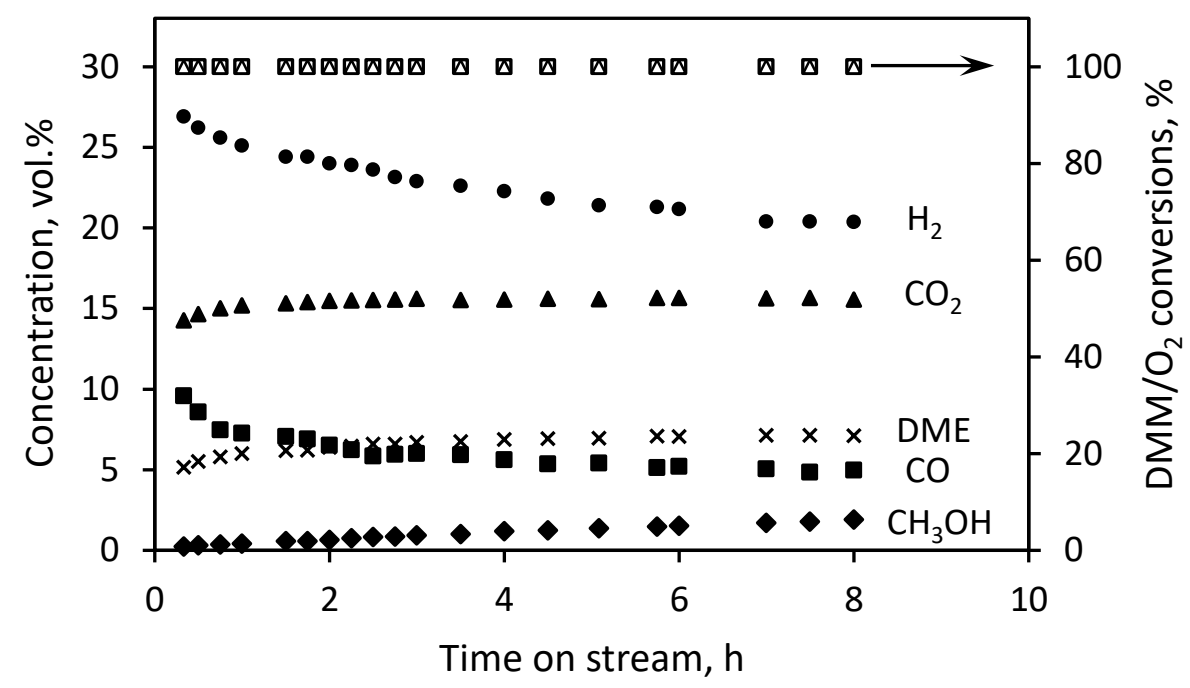

Figure 2. Effect of time-on-stream on DMM conversion and product concentrations in DMM partial oxidation over the $\mathrm{CuO}-\mathrm{CeO}_{2} / \gamma-\mathrm{Al}_{2} \mathrm{O}_{3}$ catalyst. Reaction conditions: $\mathrm{P}=1 \mathrm{~atm} ; \mathrm{T}=280{ }^{\circ} \mathrm{C}$; GHSV $=10,000 \mathrm{~h}^{-1}$; Inlet composition: $\mathrm{CH}_{3} \mathrm{OCH}_{2} \mathrm{OCH}_{3}: \mathrm{O}_{2}: \mathrm{N}_{2}=16.7: 16.7: 66.6$ vol. $\%$.

\subsection{DMM Oxidative Steam Reforming}

One should note that a catalyst active for both $\mathrm{SR}$ and $\mathrm{PO}$ reactions is expected to be effective for the OSR reaction. Since $\mathrm{CuO}-\mathrm{CeO}_{2} / \gamma-\mathrm{Al}_{2} \mathrm{O}_{3}$ catalyst was active for DMM PO and DMM SR (see above Section 3.1 and our previous works [8,9]), we studied its behavior in DMM OSR.

The influence of the inlet composition on the catalytic performance of the $\mathrm{CuO}-\mathrm{CeO}_{2} / \gamma-\mathrm{Al}_{2} \mathrm{O}_{3}$ in DMM OSR is shown in Table 1 . This study was performed at $280{ }^{\circ} \mathrm{C}$ using a constant concentration of DMM (10 vol.\%) in DMM SR (composition 1), DMM OSR (composition 2 and 3) and DMM PO (composition 4). $\mathrm{H}_{2} \mathrm{O}, \mathrm{O}_{2}$ and $\mathrm{N}_{2}$ content in the reaction mixture was varied as shown in Table 1 . Total GHSV was maintained at $15,000 \mathrm{~h}^{-1}$. The higher GHSV was chosen in order to clearly demonstrate the effect of the reaction composition. Note that $\mathrm{H}_{2}, \mathrm{CO}_{2}, \mathrm{CO}$, DME and methanol were the main noticeable reaction products. The catalytic data in the table were obtained $1 \mathrm{~h}$ after the start of catalyst testing.

Table 1. Effect of inlet reaction mixture on hydrogen productivity and yield in DMM OSR ${ }^{1}$ over the $\mathrm{CuO}-\mathrm{CeO}_{2} / \gamma-\mathrm{Al}_{2} \mathrm{O}_{3}$ catalyst.

\begin{tabular}{|c|c|c|c|c|c|c|}
\hline \multirow{2}{*}{\multicolumn{2}{|c|}{ Inlet Reaction Mixture DMM: $\mathrm{O}_{2}: \mathrm{H}_{2} \mathrm{O}: \mathrm{N}_{2}$, vol.\% }} & \multirow{2}{*}{$\mathrm{W}\left(\mathrm{H}_{2}\right), \mathrm{L} \mathrm{h}^{-1} \mathrm{~g}_{\mathrm{cat}}{ }^{-1}$} & \multicolumn{4}{|c|}{ Yield, \% } \\
\hline & & & $\mathrm{CO}_{2}$ & $\mathrm{CO}$ & $\mathrm{CH}_{3} \mathrm{OCH}_{3}$ & $\mathrm{CH}_{3} \mathrm{OH}$ \\
\hline 1 & $10: 0: 45: 45$ & 12.4 & 82 & 1.4 & 4 & 12.6 \\
\hline 2 & $10: 2.5: 40: 47.5$ & 14 & 87.7 & 1.8 & 3.2 & 7.3 \\
\hline 3 & $10: 5: 25: 60$ & 10 & 70.6 & 3.3 & 16.6 & 9.5 \\
\hline 4 & $10: 10: 0: 80$ & 5 & 43 & 21 & 34 & 1 \\
\hline
\end{tabular}

${ }^{1}$ Reaction conditions: $\mathrm{P}=1 \mathrm{~atm}, \mathrm{~T}=280{ }^{\circ} \mathrm{C}$ and GHSV $=15,000 \mathrm{~h}^{-1}$.

As reported earlier, the $\mathrm{CuO}-\mathrm{CeO}_{2} / \gamma-\mathrm{Al}_{2} \mathrm{O}_{3}$ catalyst provides excellent performance in DMM SR. A special experiment (composition 1, see Table 1) showed that $\mathrm{H}_{2}$ productivity reached $12.4 \mathrm{~L} \mathrm{~h}^{-1} \mathrm{~g}_{\text {cat }}{ }^{-1}$, $\mathrm{CO}_{2}$ selectivity- $82 \%$. In our OSR experiments, the $\mathrm{H}_{2} \mathrm{O}$ concentration in the reaction mixture was gradually decreased, while the $\mathrm{O}_{2}$ concentration increased. Table 1 shows that the catalyst performance increased notably as $\mathrm{O}_{2}$ was added in an amount of 2.5 vol.\% to the DMM SR reaction mixture (composition 2): the $\mathrm{H}_{2}$ productivity and $\mathrm{CO}_{2}$ yield increased up to $14 \mathrm{~L} \mathrm{~h}^{-1} \mathrm{~g}_{\text {cat }}{ }^{-1}$ and $~ 88 \%$, respectively, mainly due to the consumption of methanol (its yield decreased from 12.6 to $7.3 \mathrm{vol} . \%$ ). At the same time, a slight increase in CO yield was observed. 
The catalyst behavior in DMM OSR was sensitive to both $\mathrm{H}_{2} \mathrm{O}$ and $\mathrm{O}_{2}$ content in the reaction mixture. As the $\mathrm{H}_{2} \mathrm{O}$ concentration decreased below 40 vol.\%, that is the stoichiometric value for DMM SR, the hydrogen productivity reduced significantly (composition 3 ). This observation is most likely associated with the fact that water deficiency promotes the side reaction of DMM decomposition (Equation (2)), leading to undesired $\mathrm{CO}$ and DME formation. Further addition of $\mathrm{O}_{2}$ and the progressive decrease of $\mathrm{H}_{2} \mathrm{O}$ concentration to 0 led to a decrease in the $\mathrm{H}_{2}$ productivity down to $5 \mathrm{~L} \mathrm{~h}^{-1} \mathrm{~g}_{\text {cat }}{ }^{-1}$ due to the predominant proceeding of DMM decomposition and partial oxidation reactions.

Comparative studies (Table 1) have shown the high promise of DMMOSR to produce hydrogen-rich gas. In particular, the DMM SR process was significantly promoted by a small $\mathrm{O}_{2}$ additive $(2.5 \mathrm{vol} . \%)$ resulting in an increase in $\mathrm{H}_{2}$ productivity and a decrease in by-product formation in sum. As seen in Figure 3, the catalyst performance was sensitive to the $\mathrm{O}_{2}$ addition in a wide range of temperatures between 200 and $300{ }^{\circ} \mathrm{C}$ in terms of DMM conversion and $\mathrm{H}_{2}$ outlet concentration. The fundamental reason behind such behavior is likely related to the chemical state of copper in the active catalyst. It is claimed that $\mathrm{O}_{2}$ in the reaction mixture causes oxidation of surface copper particles, which leads to the formation of $\mathrm{Cu}^{+}$or $\mathrm{Cu}_{2} \mathrm{O}$ species that improve the catalyst activity in methanol [27-29] and DME [30] reforming to hydrogen-rich gas.

The optimum composition of reagents for DMM OSR over the $\mathrm{CuO}-\mathrm{CeO}_{2} / \gamma-\mathrm{Al}_{2} \mathrm{O}_{3}$ catalyst is as follows: DMM: $\mathrm{O}_{2}: \mathrm{H}_{2} \mathrm{O}: \mathrm{N}_{2}=10: 2.5: 40: 47.5$ (vol.\%). This composition provided the maximum $\mathrm{H}_{2}$ productivity; therefore, it was chosen for further studies.

Figure 4 shows the effect of temperature on the outlet product concentration for DMM OSR over the $\mathrm{CuO}-\mathrm{CeO}_{2} / \gamma-\mathrm{Al}_{2} \mathrm{O}_{3}$ catalyst. The experiment was carried out using the inlet reaction mixture DMM: $\mathrm{O}_{2}: \mathrm{H}_{2} \mathrm{O}: \mathrm{N}_{2}=10: 2.5: 40: 47.5$ (vol. $\%$ ) and GHSV $=10,000 \mathrm{~h}^{-1}$. The equilibrium values of product concentrations were calculated in the assumption that $\mathrm{H}_{2}, \mathrm{CO}_{2}, \mathrm{CO}, \mathrm{CH}_{3} \mathrm{OH}, \mathrm{CH}_{2} \mathrm{O}$ and $\mathrm{CH}_{3} \mathrm{OCH}_{3}$ were formed during the DMM OSR reaction. The equilibrium concentrations of oxygenates $\left(\mathrm{CH}_{3} \mathrm{OH}\right.$, $\mathrm{CH}_{2} \mathrm{O}, \mathrm{CH}_{3} \mathrm{OCH}_{3}$ and $\mathrm{CH}_{3} \mathrm{OCH}_{2} \mathrm{OCH}_{3}$ ) did not exceed $6 \times 10^{-3}$ vol.\%, and are not shown in Figure 4 .

As shown in Figure 3, complete DMM conversion during DMM OSR over the $\mathrm{CuO}-\mathrm{CeO}_{2} / \gamma-\mathrm{Al}_{2} \mathrm{O}_{3}$ catalyst was reached at temperatures above $200^{\circ} \mathrm{C}$. Note that the temperature dependencies of the outlet product concentrations for DMM OSR were generally similar to those for DMM SR [8,9], but shifted to a lower temperature region. Similar to DMM SR, DME formation in DMM OSR was observed at temperatures $250-300{ }^{\circ} \mathrm{C}$ in amounts below 0.3 vol. $\%$ and is not shown in Figure 4.

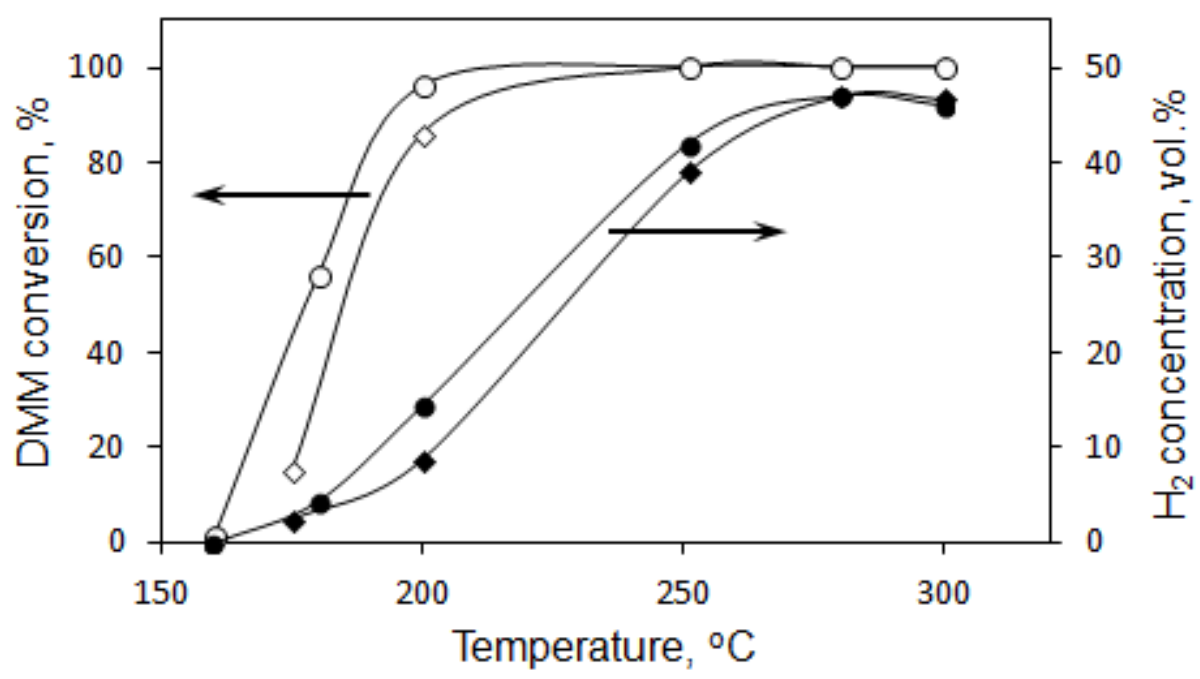

Figure 3. Effect of temperature on DMM conversion and outlet $\mathrm{H}_{2}$ concentration in DMM steam reforming $(\diamond \bullet)$ and oxidative steam reforming $(\bigcirc \bullet)$ over $\mathrm{CuO}-\mathrm{CeO}_{2} / \gamma-\mathrm{Al}_{2} \mathrm{O}_{3}$ catalyst. Reaction conditions: $\mathrm{P}=1 \mathrm{~atm}$, inlet composition, vol.\%: DMM: $\mathrm{H}_{2} \mathrm{O}: \mathrm{N}_{2}=10: 45: 45$ for DMM SR and DMM:O $\mathrm{O}_{2}: \mathrm{H}_{2} \mathrm{O}: \mathrm{N}_{2}=10: 2.5: 40: 47.5$ for DMM OSR, GHSV $=10,000 \mathrm{~h}^{-1}$. 


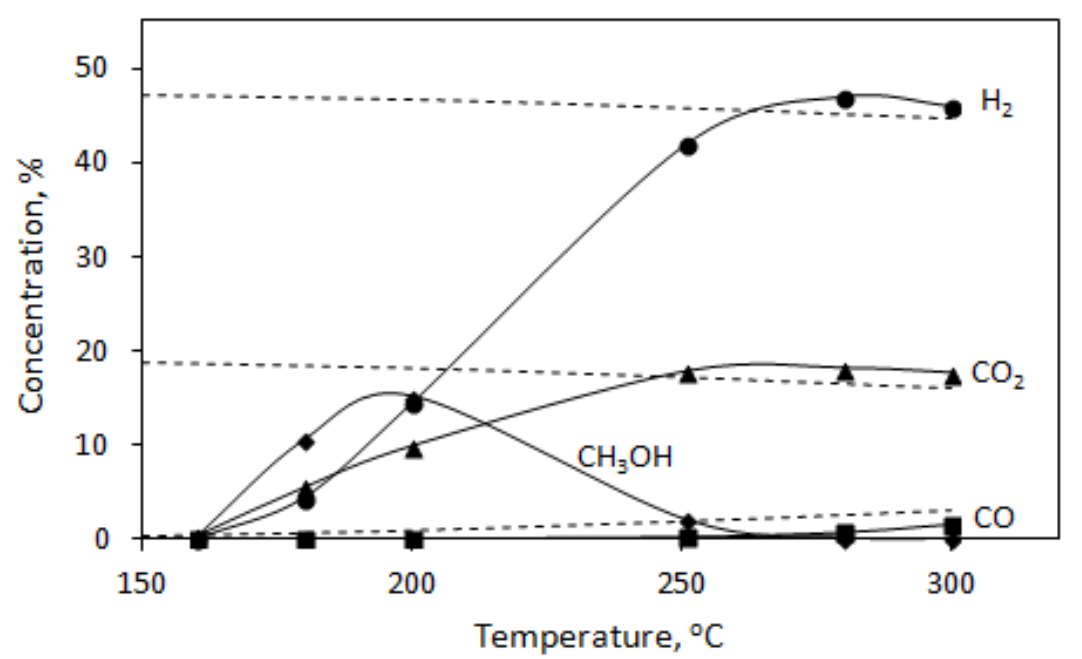

Figure 4. Effect of temperature on the outlet concentrations in DMM oxidative steam reforming over $\mathrm{CuO}-\mathrm{CeO}_{2} / \gamma-\mathrm{Al}_{2} \mathrm{O}_{3}$ catalyst. Reaction conditions: $\mathrm{P}=1 \mathrm{~atm}$, inlet composition, vol.\%: DMM: $\mathrm{O}_{2}: \mathrm{H}_{2} \mathrm{O}: \mathrm{N}_{2}=10: 2.5: 40: 47.5$ and GHSV $=10,000 \mathrm{~h}^{-1}$. Solid lines-experiment, dotted lines-thermodynamic equilibrium values.

As Figure 4 shows, methanol was the main reaction product in DMM OSR at temperatures below $200{ }^{\circ} \mathrm{C}$. The $\mathrm{CH}_{3} \mathrm{OH}$ concentration increased with temperature and passed through a maximum at $200{ }^{\circ} \mathrm{C}$, then gradually reduced with further increasing temperature and fell to $\sim 0$ at $300{ }^{\circ} \mathrm{C}$. Such dependence is in agreement with the previously proposed consecutive kinetic scheme of DMM SR [6-12]. According to this scheme, methanol and formaldehyde are produced as intermediates by DMM hydrolysis (8) on the $\gamma-\mathrm{Al}_{2} \mathrm{O}_{3}$ surface. However, during the catalyst testing, we did not observe the formation of formaldehyde, most likely, as mentioned above, due to its higher reactivity in the steam reforming (9) reaction over Cu-containing species [26] as compared to that of methanol (11).

The $\mathrm{H}_{2}$ and $\mathrm{CO}_{2}$ outlet concentrations increased with temperature and slightly exceeded respective equilibrium values at $280-300{ }^{\circ} \mathrm{C}$. As for $\mathrm{CO}$, a noticeable amount was observed at $250{ }^{\circ} \mathrm{C}$. The $\mathrm{CO}$ concentration increased from 0.17 to 1.6 vol.\% as the temperature increased from 250 to $300{ }^{\circ} \mathrm{C}$. Nevertheless, the $\mathrm{CO}$ concentration was significantly lower than its equilibrium value. This behavior is related to the fact that $\mathrm{H}_{2}$ and $\mathrm{CO}_{2}$ are the primary products of formaldehyde (9) and methanol steam reforming (11), while CO is produced by reverse Water Gas Shift (WGS) reaction (13). Apparently, if the WGS reaction does not reach equilibrium in DMM OSR, the $\mathrm{H}_{2}$ and $\mathrm{CO}_{2}$ outlet concentrations should exceed respective equilibrium values and the $\mathrm{CO}$ concentration should remain below it.

$$
\mathrm{H}_{2}+\mathrm{CO}_{2}=\mathrm{H}_{2} \mathrm{O}+\mathrm{CO}
$$

Thus, the data shown in Figure 4 prove that the favorable DMM OSR operation temperature to produce the maximum amount of $\mathrm{H}_{2}$ over the $\mathrm{CuO}-\mathrm{CeO}_{2} / \gamma-\mathrm{Al}_{2} \mathrm{O}_{3}$ catalyst is $\sim 280^{\circ} \mathrm{C}$. Moreover, as seen in Figure 5, the catalyst provides good stability during DMM OSR. The results prove there was no catalyst deactivation at $280^{\circ} \mathrm{C}$ and GHSV $=15000 \mathrm{~h}^{-1}$ for $10 \mathrm{~h}$ on-stream. Under these conditions, $\mathrm{H}_{2}$ productivity reached $14 \mathrm{~L} \mathrm{~h}^{-1} \mathrm{~g}_{\mathrm{cat}}{ }^{-1}$ and the outlet $\mathrm{CO}$ concentration was less than 0.4 vol.\%.

Impact of GHSV on the catalytic behavior of the $\mathrm{CuO}-\mathrm{CeO}_{2} / \gamma-\mathrm{Al}_{2} \mathrm{O}_{3}$ in $\mathrm{DMM}$ OSR is shown in Figure 6. The data on DMM conversion and product yields were obtained at $300{ }^{\circ} \mathrm{C}$ using the inlet reaction mixture composed of (vol.\%): $10 \mathrm{DMM}, 40 \mathrm{H}_{2} \mathrm{O}, 2.5 \mathrm{O}_{2}$ and $47.5 \mathrm{~N}_{2}$ at GHSV $=10,000-40,000 \mathrm{~h}^{-1}$. Under these conditions, the DMM conversion was $100 \%$. At GHSV $=10,000-15,000 \mathrm{~h}^{-1}$, the catalyst contact time was sufficient to effectively convert DMM to $\mathrm{H}_{2}$ and $\mathrm{CO}_{2}$ with $\sim 90 \%$ yields. Therefore, the GHSV should be set at 10,000-15,000 $\mathrm{h}^{-1}$ for efficient DMM OSR operation. Further increasing the velocity to $40,000 \mathrm{~h}^{-1}$ led to a significant decrease in the $\mathrm{H}_{2}$ and $\mathrm{CO}_{2}$ yields to $60-70 \%$ while the methanol and DME yields increased. 


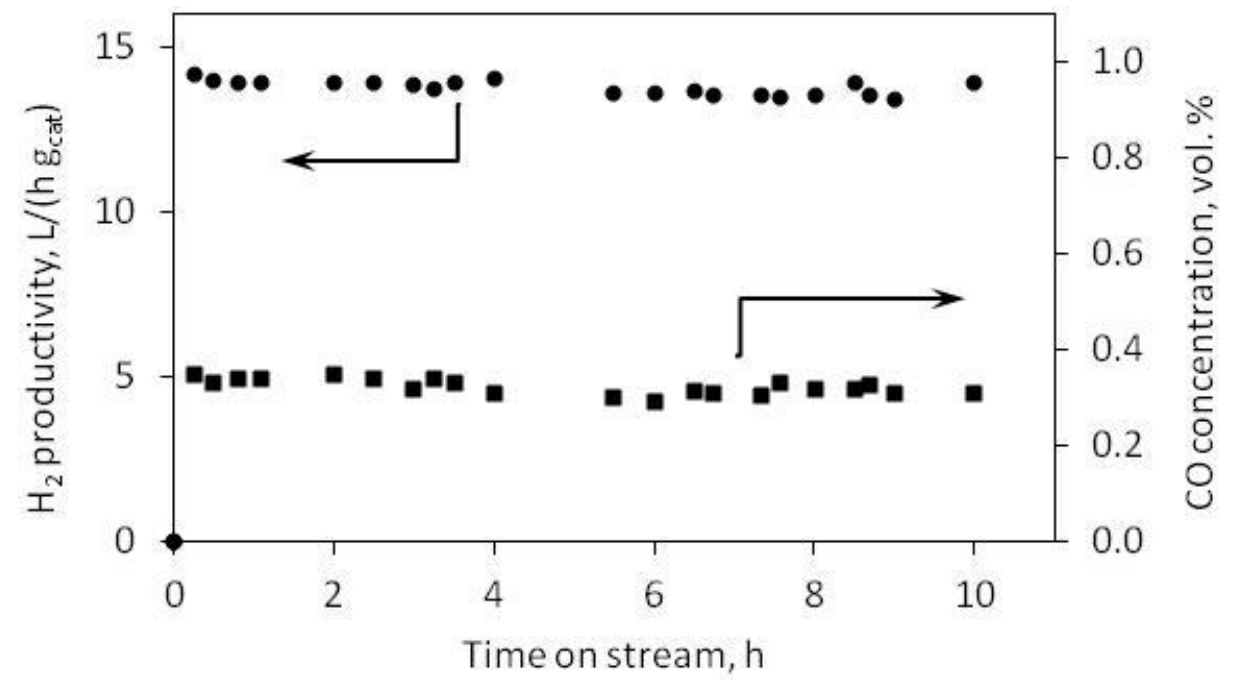

Figure 5. Effect of time-on-stream on hydrogen productivity and CO outlet concentrations in DMM oxidative steam reforming (OSR) over $\mathrm{CuO}-\mathrm{CeO}_{2} / \gamma-\mathrm{Al}_{2} \mathrm{O}_{3}$ catalyst. Reaction conditions: $\mathrm{P}=1 \mathrm{~atm}$, $\mathrm{T}=280{ }^{\circ} \mathrm{C}, \mathrm{GHSV}=15,000 \mathrm{~h}^{-1}$; Inlet composition, vol. $\%:$ DMM: $\mathrm{O}_{2}: \mathrm{H}_{2} \mathrm{O}: \mathrm{N}_{2}=10: 2.5: 40: 47.5$.

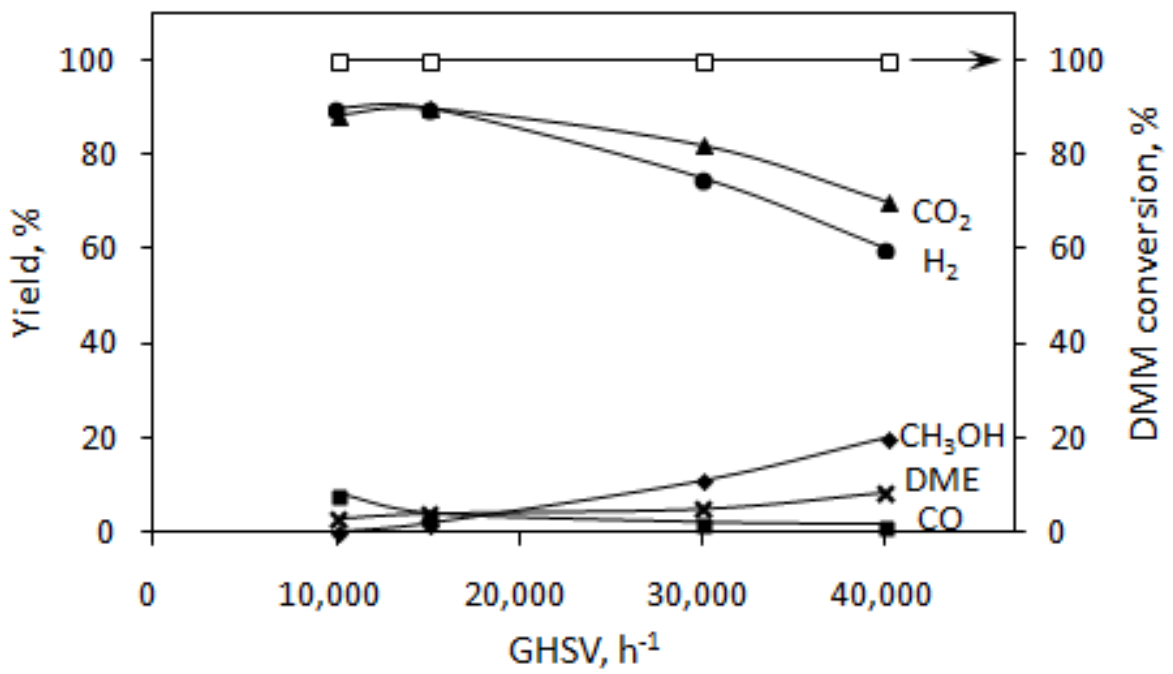

Figure 6. Effect of GHSV on catalyst performance in DMM oxidative steam reforming over CuO- $\mathrm{CeO}_{2} / \gamma-\mathrm{Al}_{2} \mathrm{O}_{3}$ catalyst. Reaction conditions: $\mathrm{P}=1 \mathrm{~atm} ; \mathrm{T}=300{ }^{\circ} \mathrm{C}$; Inlet composition: DMM: $\mathrm{O}_{2}: \mathrm{H}_{2} \mathrm{O}: \mathrm{N}_{2}=10: 2.5: 40: 47.5$ vol. $\%$.

Note again that the reagents in our lab-scale experiments were diluted by a significant amount of nitrogen to correctly evaluate the catalytic performance. Obviously, commercial DMM fuel reformer for fuel cell feeding applications should contain no additional diluents in the reagents, except the nitrogen of air required for DMM OSR operation. We made some calculations excluding excess nitrogen in order to evaluate the real composition of hydrogen-rich gas. The simulation results show that DMM OSR (with inlet mixture DMM: $\mathrm{H}_{2} \mathrm{O}: \mathrm{air}=16: 64: 20$ vol.\%) over the $\mathrm{CuO}-\mathrm{CeO}_{2} / \gamma-\mathrm{Al}_{2} \mathrm{O}_{3}$ catalyst can produce a gas mixture containing $\sim 60 \mathrm{vol} . \% \mathrm{H}_{2}$ with low (1 vol.\%) $\mathrm{CO}$ content. As stated in [31], a gas mixture with this composition can be used directly for feeding high-temperature polymer electrolyte membrane (PEM) fuel cells. For low-temperature PEM fuel cell feeding, the gas mixture needs to be purified up to $10 \mathrm{ppm}$ of $\mathrm{CO}$, for example, by selective $\mathrm{CO}$ methanation [32].

\section{Conclusions}

Using the $\mathrm{CuO}-\mathrm{CeO}_{2} / \gamma-\mathrm{Al}_{2} \mathrm{O}_{3}$ catalyst, the feasibility of hydrogen production by partial oxidation and oxidative steam reforming of DMM was shown for the first time. The oxidative steam reforming of 
DMM was more efficient for hydrogen production than steam reforming and partial oxidation of DMM. In particular, the DMM steam reforming process was significantly promoted by a small $\mathrm{O}_{2}$ additive that resulted in an increase in the DMM conversion and $\mathrm{H}_{2}$ productivity. The $\mathrm{CuO}-\mathrm{CeO}_{2} / \gamma-\mathrm{Al}_{2} \mathrm{O}_{3}$ catalyst provided complete conversion of $\mathrm{DMM}$ to hydrogen-rich gas with a high production rate $\left(>14 \mathrm{~L} \mathrm{~h}^{-1} \mathrm{~g}_{\mathrm{cat}}{ }^{-1}\right)$ and low CO content $(\sim 1 \mathrm{vol} . \%)$ at $280-300{ }^{\circ} \mathrm{C}$ using the reaction mixture DMM: $\mathrm{O}_{2}: \mathrm{H}_{2} \mathrm{O}: \mathrm{N}_{2}=10: 2.5: 40: 47.5$ (vol.\%) and GHSV $=15,000 \mathrm{~h}^{-1}$. The results obtained show that an efficient $\mathrm{CuO}-\mathrm{CeO}_{2} / \gamma-\mathrm{Al}_{2} \mathrm{O}_{3}$ catalyst has been proposed for the oxidative steam reforming of DMM. It shows high promise for polymer electrolyte membrane fuel cell feeding applications.

Author Contributions: Conceptualization, methodology, investigation, writing一original draft preparation, S.B.; supervision, V.S.; All authors have read and agreed to the published version of the manuscript.

Funding: This work was supported by Ministry of Science and Higher Education of the Russian Federation (Project AAAA-A17-117041710088-0).

Conflicts of Interest: The authors declare no conflicts of interest.

\section{References}

1. Felseghi, R.-A.; Carcadea, E.; Raboaca, M.S.; Trufin, C.N.; Filote, C. Hydrogen fuel cell technology for the sustainable future of stationary applications. Energies 2019, 12, 4593. [CrossRef]

2. Simon Araya, S.; Liso, V.; Cui, X.; Li, N.; Zhu, J.; Sahlin, S.L.; Jensen, S.H.; Nielsen, M.P.; Kær, S.K. A review of the methanol economy: The fuel cell route. Energies 2020, 13, 596. [CrossRef]

3. Navarro, R.M.; Pena, M.A.; Fierro, J.L.G. Hydrogen Production Reactions from Carbon Feedstocks: Fossil Fuels and Biomass. Chem. Rev. 2007, 107, 3952-3991. [CrossRef] [PubMed]

4. Li, D.; Li, X.; Gong, J. Catalytic Reforming of Oxygenates: State of the Art and Future Prospects. Chem. Rev. 2016, 116, 11529-11653. [CrossRef]

5. Zyryanova, M.M.; Badmaev, S.D.; Belyaev, V.D.; Amosov, Y.I.; Snytnikov, P.V.; Kirillov, V.A.; Sobyanin, V.A. Catalytic reforming of hydrocarbon feedstocks into fuel for power generation units. Catal. Ind. 2013, 5, 312-317. [CrossRef]

6. Sun, Q.; Auroux, A.; Shen, J. Surface acidity of niobium phosphate and steam reforming of dimethoxymethane over $\mathrm{CuZnO} / \mathrm{Al}_{2} \mathrm{O}_{3}-\mathrm{NbP}$ complex catalysts. J. Catal. 2006, 244, 1-9. [CrossRef]

7. $\mathrm{Fu}, \mathrm{Y}$; Shen, J. Production of hydrogen by catalytic reforming of dimethoxymethane over bifunctional catalysts. J. Catal. 2007, 248, 101-110. [CrossRef]

8. Badmaev, S.D.; Pechenkin, A.A.; Belyaev, V.D.; Ven'yaminov, S.A.; Snytnikov, P.V.; Sobyanin, V.A.; Parmon, V.N. Steam reforming of dimethoxymethane to hydrogen-rich gas for fuel cell feeding application. Dokl. Phys. Chem. 2013, 452, 251-253. [CrossRef]

9. Pechenkin, A.A.; Badmaev, S.D.; Belyaev, V.D.; Sobyanin, V.A. Performance of bifunctional $\mathrm{CuO}-\mathrm{CeO}_{2} / \gamma-\mathrm{Al}_{2} \mathrm{O}_{3}$ catalyst in dimethoxymethane steam reforming to hydrogen-rich gas for fuel cell feeding. Appl. Catal. B Environ. 2015, 166, 535-543. [CrossRef]

10. Badmaev, S.D.; Pechenkin, A.A.; Belyaev, V.D.; Sobyanin, V.A. Hydrogen production by steam reforming of dimethoxymethane over bifunctional $\mathrm{CuO}-\mathrm{ZnO} / \gamma-\mathrm{Al}_{2} \mathrm{O}_{3}$ catalyst. Int. J. Hydrog. Energy 2015, 40, 14052-14057. [CrossRef]

11. Pechenkin, A.A.; Badmaev, S.D.; Belyaev, V.D.; Sobyanin, V.A. Steam reforming of dimethoxymethane, methanol and dimethyl ether on $\mathrm{CuO}-\mathrm{ZnO} / \gamma-\mathrm{Al}_{2} \mathrm{O}_{3}$ catalyst. Kinet. Catal. 2017, 58, 577-584. [CrossRef]

12. Badmaev, S.D.; Sobyanin, V.A. Steam reforming of dimethoxymethane to hydrogen-rich gas over bifunctional $\mathrm{CuO}-\mathrm{ZnO} / \eta-\mathrm{Al}_{2} \mathrm{O}_{3}$ catalyst-coated FeCrAl wire mesh. Catal. Today 2020, 348, 9-14. [CrossRef]

13. Pechenkin, A.A.; Badmaev, S.D.; Belyaev, V.D.; Sobyanin, V.A. Production of hydrogen-rich gas by formic acid decomposition over $\mathrm{CuO}-\mathrm{CeO}_{2} / \gamma-\mathrm{Al}_{2} \mathrm{O}_{3}$ catalyst. Energies 2019, 12, 3577. [CrossRef]

14. Thattarathody, R.; Katheria, S.; Sheintuch, M. Methylal Steam Reforming with $\mathrm{Pt} / \mathrm{Al}_{2} \mathrm{O}_{3}, \mathrm{Ni} / \mathrm{Al}_{2} \mathrm{O}_{3}$, and Mixed $\mathrm{Cu} / \mathrm{ZnO} / \mathrm{Al}_{2} \mathrm{O}_{3}$ Catalysts. Ind. Eng. Chem. Res. 2019, 58, 21382-21391. [CrossRef]

15. Thattarathody, R.; Sheintuch, M. Product composition and kinetics of methylal decomposition on alumina-supported Pt, Ni, and Rh catalysts. Ind. Eng. Chem. Res. 2019, 58, 11902-11909. [CrossRef]

16. Badmaev, S.D.; Akhmetov, N.O.; Sobyanin, V.A. Partial oxidation of dimethoxymethane to syngas over supported noble metal catalysts. Top. Catal. 2020, 63, 196-202. [CrossRef] 
17. Kaichev, V.V.; Popova, G.Y.; Chesalov, Y.A.; Saraev, A.A.; Zemlyanov, D.Y.; Beloshapkin, S.A.; Knop-Gericke, A.; Schlögl, R.; Andrushkevich, T.V. Selective oxidation of methanol to form dimethoxymethane and methyl formate over a monolayer $\mathrm{V}_{2} \mathrm{O}_{5} / \mathrm{TiO}_{2}$ catalyst. J. Catal. 2014, 311, 59-70. [CrossRef]

18. Sturt, N.R.M.; Terra, J.C.S.; Lara Sangiorge, D.; Oliveira, L.C.A.; Moura, F.C.C. Performance of niobium catalysts in a one-pot system for selective methanol conversion to dimethoxymethane under mild conditions. Fuel 2020, 262, 116417-116428. [CrossRef]

19. Sun, R.; Delidovich, I.; Palkovits, R. Dimethoxymethane as a Cleaner Synthetic Fuel: Synthetic Methods, Catalysts, and Reaction Mechanism. ACS Catal. 2019, 9, 1298-1318. [CrossRef]

20. Velu, S.; Suzuki, K.; Okazaki, M.; Kapoor, M.P.; Osaki, T.; Ohashi, F. Oxidative Steam Reforming of Methanol over $\mathrm{CuZnAl}(\mathrm{Zr})-O x i d e$ Catalysts for the Selective Production of Hydrogen for Fuel Cells: Catalyst Characterization and Performance Evaluation. J. Catal. 2000, 194, 373-384. [CrossRef]

21. Velu, S.; Suzuki, K. Selective Production of Hydrogen for Fuel Cells via Oxidative Steam Reforming of Methanol over CuZnAl Oxide Catalysts: Effect of Substitution of Zirconium and Cerium on the Catalytic Performance. Top. Catal. 2003, 22, 235-244. [CrossRef]

22. Jiménez-González, C.; Gil-Calvo, M.; de Rivas, B.; González-Velasco, J.R.; Gutiérrez-Ortiz, J.I.; López-FonsecaInd, R. Oxidative Steam Reforming and Steam Reforming of Methane, Isooctane, and N-Tetradecane over an Alumina Supported Spinel-Derived Nickel Catalyst. Ind. Eng. Chem. Res. 2016, 55, 3920-3929. [CrossRef]

23. Chi, H.; Andolina, C.M.; Li, J.; Curnan, M.T.; Saidi, W.A.; Zhou, G.; Yang, J.C.; Veser, G. Dependence of $\mathrm{H}_{2}$ and $\mathrm{CO}_{2}$ selectivity on $\mathrm{Cu}$ oxidation state during partial oxidation of methanol on $\mathrm{Cu} / \mathrm{ZnO}$. Appl. Catal. 2018, 556, 64-72. [CrossRef]

24. Badmaev, S.D.; Akhmetov, N.O.; Pechenkin, A.A.; Sobyanin, V.A.; Parmon, V.N. Low-temperature partial oxidation of dimethyl ether to hydrogen-rich gas over $\mathrm{CuO}-\mathrm{CeO}_{2} / \gamma-\mathrm{Al}_{2} \mathrm{O}_{3}$ catalysts for fuel cell supply. Dokl. Phys. Chem. 2019, 487, 95-98. [CrossRef]

25. Badmaev, S.D.; Akhmetov, N.O.; Belyaev, V.D.; Kulikov, A.V.; Pechenkin, A.A.; Potemkin, D.I.; Konishcheva, M.V.; Rogozhnikov, V.N.; Snytnikov, P.V.; Sobyanin, V.A. Syngas production via partial oxidation of dimethyl ether over $\mathrm{Rh} / \mathrm{Ce}_{0.75} \mathrm{Zr}_{0.25} \mathrm{O}_{2}$ catalyst and its application for SOFC feeding. Int. J. Hydrog. Energy 2020. [CrossRef]

26. Takezawa, N.; Iwasa, N. Steam reforming and dehydrogenation of methanol: Difference in the catalytic functions of copper and group VIII metals. Catal. Today 1997, 36, 45-56. [CrossRef]

27. Murcia-Mascaros, S.; Navarro, R.M.; Gomez-Sainero, L.; Constantino, U.; Nocchetti, M.; Fierro, J.L.G. Oxidative methanol reforming reactions on $\mathrm{CuZnAl}$ catalysts derived from hydrotalcite-like precursors. J. Catal. 2001, 198, 338-347. [CrossRef]

28. Carrazan, S.R.G.; Wojcieszak, R.; Blanco, R.M.; Mateos-Pedrero, C.; Ruiz, P. Modulation of the selectivity in partial oxidation of methanol over $\mathrm{CuZnAl}$ catalysts by adding $\mathrm{CO}_{2}$ and/or $\mathrm{H}_{2}$ into the reaction feed. Appl. Catal. B Environ. 2015, 168, 14-24. [CrossRef]

29. Sun, Z.; Zhang, X.; Li, H.; Liu, T.; Sang, S.; Chen, S.; Duan, L.; Zeng, L.; Xiang, W.; Gong, J. Chemical looping oxidative steam reforming of methanol: A new pathway for auto-thermal conversion. Appl. Catal. B Environ. 2020, 269, 118758. [CrossRef]

30. Zhou, X.; Meng, M.; Sun, Z.; Li, Q.; Jiang, Z. Prominent enhancement of Mn or Co addition on the performance of $\mathrm{Cu}-\mathrm{Ce}-\mathrm{O}$ catalyst used for $\mathrm{H}_{2}$ production via dimethyl ether steam reforming. Chem. Eng. J. 2011, 174, 400-407. [CrossRef]

31. Chandan, A.; Hattenberger, M.; El-kharouf, A.; Du, S.; Dhir, A.; Self, V.; Pollet, B.G.; Ingram, A.; Bujalski, W. High temperature (HT) polymer electrolyte membrane fuel cells (PEMFC)-A review. J. Power Sources 2013, 231, 264-278. [CrossRef]

32. Garbis, P.; Kern, C.; Jess, A. Kinetics and reactor design aspects of selective methanation of CO over a $\mathrm{Ru} / \gamma-\mathrm{Al}_{2} \mathrm{O}_{3}$ catalyst in $\mathrm{CO}_{2} / \mathrm{H}_{2}$ rich gases. Energies 2019, 12, 469. [CrossRef]

(C) 2020 by the authors. Licensee MDPI, Basel, Switzerland. This article is an open access article distributed under the terms and conditions of the Creative Commons Attribution (CC BY) license (http://creativecommons.org/licenses/by/4.0/). 